\title{
Protective Effect of Angiotensin II Type 1-Receptor-Blocker on Diabetic Nephropathy in Rats: Role of Nephrin
}

\author{
ALAA I. ALI, M.D.*; DOAA A. ABDEL MOETY, M.D.**; EBTESAM M. IBRAHIM, M.D.** and \\ MAHMOUD M.A. ABULMEATY, M.D.** \\ The Departments of Clinical Pharmacology* and Medical Physiology**, Faculty of Medicine, Zagazig University
}

\begin{abstract}
Background: Angiotensin II-Receptor Blockers (ARBs) has a questionable nephroprotective effect especially in diabetic nephropathy. Nephrin protein molecules exist in the slit diaphragm of the glomerular filtration membrane and control the passage of plasma protein.
\end{abstract}

Aim of Study: To examine the possible role of Nephrin in the pathogenesis of diabetic nephropathy and the protective effect of ATII-RB (candesartan) on diabetic nephropathy.

Material and Methods: Thirty-two male rats were used in this experiment. Half of the rats were fed a high-fat diet (HFD) and the other half were fed a standard diet for 4 weeks. A model of diabetic nephropathy (DN) was created by a $35 \mathrm{mg} / \mathrm{kg}$ intraperitoneal dose of Streptozotocin (STZ) in the HFD-fed rats. Then the rats were divided into four groups $(8$ rats/group). (1) Normal control (NC) group; (2) Diabetic nephropathy (DN) group; (3) ARB-treated NC group: Normal rats were treated with the ARB (Candesartan Cilexetil), in a dose $0.1 \mathrm{mg} / \mathrm{kg}$; (4) ARB-treated DN group: The rats with DN and received the above dose of candesartan for 4 weeks.

The urine was collected to measure the urine flow rate, urinary concentrations of Nephrin, creatinine, and protein. Blood samples were used to measure urea, creatinine, glucose, insulin, and the homeostatic model assessment (HOMA-IR). Then renal tissue samples were used to measure Superoxide dismutase (SOD) activity and Malondialdehyde (MDA) in addition to histopathological examination. The mean arterial blood pressure (MABP) was also recorded.

Results: Candesartan treatment in the DN group showed significant reductions of glucose, HOMA-IR, amelioration of renal antioxidant system, reductions in creatinine, reduction of proteinuria, reduction of urinary Nephrin, and MABP. Histological improvement was also detected in the form of mild glomerulosclerosis and interstitial fibrosis. The urinary Nephrin was 90 times high in the condition of DN. This huge rise of urinary Nephrin was significantly reduced by Candesartan treatment. Moreover, in the DN group the urinary Nephrin level showed a significant correlation with glucose level, serum creatinine, urinary protein-creatinine ratio, and MABP.

Correspondence to: Dr. Mahmoud M.A. Abulmeaty, E-Mail: dr.abulmeaty@gmail.com.
Conclusion: ATII-RB could reduce urinary Nephrin excretion and possibly alters its expression through its inhibitory effect on the reactive oxygen species, the Renin-AngiotensinAldosterone system and subsequently maintains the normal physiological activity of podocytes in rats with STZ-induced diabetic nephropathy.

Key Words: Angiotensin II-Receptor Blockers - NephrinDiabetic nephropathy.

\section{Introduction}

DIABETES mellitus (D.M) is the commonest metabolic disorder [1], that can be considered as a microangiopathic disease affecting different organs mainly kidneys, heart, eyes, and nervous system [2].

Diabetic Nephropathy represents a chronic renal disorder by non- or badly-controlled diabetics in the form of excessive proteinuria with subsequent hypoalbuminemia and conceivably generalized edema [3].

The clinical manifestations of diabetic nephropathy reflect the cellular and functional pathological changes in the glomeruli which represent the end-resultof different pathophysiological pathways in which hyperglycemia plays a pivotal role [4].

Nephrin is a recently discovered protein thatcontrols the passage of plasma protein through the glomerular barrier. Nephrin molecules exist in the slit diaphragm between the adjacent podocyte foot processes which represent the essential structure in the glomerular filtration membrane [5].

It has been reported, that the expression of Nephrin is markedly reduced in different proteinuric renal diseases including diabetic nephropathy, moreover the urinary content of Nephrin is significantly increased in diabetic kidney diseases [6]. 
The correlation between the level of Nephrin expression and certain renal diseases characterized by excessive proteinuria is not completely understood [7].

Angiotensin II-Receptor Blockers (ATII-RBs) are frequently used as first-line therapy against hypertension. The effects of ARBs based on their ability to block the Renin-Angiotensin-Aldosterone system with subsequent reduction of blood pressure [8].

Candesartan is a well-known anti-hypertensive drug that belongs to ATII-RBs, and many studies showed that candesartan has a nephroprotective effect as it could beused in diabetic nephropathy [9].

Regardless of its anti-hypertensive effect, candesartan therapy showed a significant reduction in urinary albumin excretion and improvement in kidney function tests, indicating that different mediators play an essential role in this nephroprotective effect of candesartan [10].

The present study aims to examine the possible role of Nephrin in the pathogenesis of diabetic nephropathy and the protective effect of ATII-RB (candesartan) on diabetic nephropathy.

\section{Material and Methods}

\section{Animals and study protocol:}

A total of 32male (180-200g) Wistar rats were purchased from the Faculty of Veterinary Medicine, Zagazig University, and used for this study during the period between June and September 2019. The animals were housed in the animal facility in the Faculty of Medicine, Zagazig University. Rats were left for one week before the start of the experimental protocol to be acclimatized to the new environment. Rats were fed the standardrodents' diet (Carbohydrate $62.8 \%$, fat $11.4 \%$, and protein $25.8 \%$ ) with water ad libitum. The room temperature was around $25^{\circ} \mathrm{C}$ witha light/dark cycle at 12:12 [11]. The study protocols were approved by the Institutional Research Board, and Ethics Committee, Faculty of Medicine, Zagazig University.

Later on, the feeding of rats was changed in half of them to be a High-fat diet [12] for 4 weeks (carbohydrate $21.3 \%$, fat $60.3 \%$, protein $18.4 \%$ ), while other rats were kept on the standard diet. Then HFD-fed rats were injected with a single intraperitoneal dose of Streptozotocin (SigmaAldrich, St. Louis, MO, USA), equal $35 \mathrm{mg} / \mathrm{kgin}$ citrate buffer ( $\mathrm{pH} 4.5)$ [13] to induce a model of diabetic nephropathy. Normally fed rats were injected with the same volume of normal saline. Two weeks later, rats were housed individually in the metabolic cages and divided into four groups ( 8 rats/group). (1) Normal control (NC) group: Which received only $1 \mathrm{ml}$ of 0.9 normal Saline every day by a rigid oral gavage. (2) Diabetic nephropathy (DN) group: In which blood glucose level was $>200 \mathrm{mg} / \mathrm{dl}$ by a Glucometer from rat tail blood samples and urinary protein became higher than that of the NC group [14] and received a vehicle by oral gavage. (3) ARB-treated NC group: Normal rats which were treated with the Angiotensin II Type 1-Receptor Blocker, candesartan (Candesartan Cilexetil, Astra Zeneca, Sweden), in a dose $0.1 \mathrm{mg} / \mathrm{kg}$, suspended in $0.9 \%$ normal saline solution at the volume of $1 \mathrm{ml} / \mathrm{rat}$ and administered by oral gavage [15]. (4) ARB-treated DN group: The animals with DN and received the same dose of candesartan describe above. This treatment protocol was continued for 4 weeks.

\section{Renal function assessment:}

The metabolic cages easily separate and collect the urine. The volume of 24-hour urine collection was divided in 1440 (60min x 24 hours) to calculate the urine flow in $\mathrm{ml} / \mathrm{min}$ [16]. Urinary samples were collected in Eppendorf tubes and stored in $20^{\circ} \mathrm{C}$ to measure concentrations of Nephrin, creatinine, and protein in the urine. Urinary ProteinUrinary Creatinine Ratio was calculated by dividing urinary protein concentration/urinary creatinine concentration [17]. Glomerular filtration rate $(\mathrm{ml} / \mathrm{min})$ was calculated by the creatinine clearance principle based on the following equation: GFR= urinary creatinine $\mathrm{x}$ urine flow/Serum creatinine [16].

\section{Blood sampling:}

At the end of the treatment protocol, a blood sample was collected after overnight fasting via cardiac puncture under ether anesthesia, followed immediately by the collection of the right kidney for histopathological examination. Blood samples were collected in tubes, centrifuged, and stored at $-20^{\circ} \mathrm{C}$ until the time of measurement.

\section{Biochemical analysis:}

The urinary Nephrin concentration measured by ELISA kits (LifeSpanBioSciences, Inc, USACatalogue no LS-F7323) [18]. The concentration of urinary protein was measured witha calorimetric technique using Sensiprot Kit (Labtest, Brazil Ref. no: 36). Diluted samples (1:50 dilution ratio) was were used to quantify urinary creatinine by a colorimetric enzymatic reaction (Labtest, Brazil - 
Ref. no: 27) [16]. The levelof glucose was measured by the glucose oxidase method using a Beckman Analyzer (Beckman, USA). Serum insulin levels were measured by a commercial ELISA kitaccording to the described protocol (MyBioSourceUSA Catalogue no MBS724709) [19]. The homeostatic model assessment (HOMA-IR) as an indicator of insulin insensitivity was calculated based on the following equation: Fasting insulin (U/l) $\mathrm{x}$ fasting glucose $(\mathrm{mg} / \mathrm{dl}) / 405$ [20]. Serum urea and creatinine levels were measured by commercial colorimetrickits (Spinreact, S.A.U. Spain).

\section{Assessment of renal antioxidant system:}

Tissue samples $(200 \mathrm{mg}$ ) of right kidney were harvested and weighed, then washed with phosphate-buffered saline to be homogenized at $4^{\circ} \mathrm{C}$ by a DY89- homogenizer (Ningbo Scientz Biotechnology Co., Ltd., Ningbo, China), the homogenates were centrifuged and stored at $-20^{\circ} \mathrm{C}$ until time of analysis. Superoxide dismutase (SOD) activity and Malondialdehyde (MDA) content were measured using commercially available kits, according to manufacturer's protocol [21]. The SOD activity was expressed in units of enzyme/mg of tissue protein while MDA in nmol/gram of tissue sample.

\section{Measurement of mean arterial blood pressure:}

A non-invasive blood pressure monitoring device (NIBP 250, serial No: 21202-108 BIOPAC system Inc; USA) was used to record the tail blood pressure. Rats were held in a restrainer on with an occlusion cuff applied on the base of the tail. The values of the systolic (SBP), diastolic (DBP) blood pressure and heart rate were demonstrated on the screen then the Mean arterial blood pressure (MABP) was calculated based on this equation $\mathrm{MAP}=\mathrm{DBP}+1 / 3(\mathrm{SBP}-\mathrm{DBP})[22]$.

\section{Histopathology:}

Immediately after decapitation, the right kidney was excised, washed with saline then fixed in $10 \%$ formalin solution and embedded in paraffin, sectioned. The sections were stained with Hematoxylin-Eosin. Stained sections were examined under a light microscope (200x) equipped with a digital camera. The pathologist was blind regarding the treatment protocol and requested to search for stigmata of glomerulosclerosis, interstitial cellular infiltration, or presence of fibrosis.

\section{Statistical analysis:}

Study parameters were presented in the form of means \pm SD and SPSS 23 was used for analysis (SPSS Inc. Chicago, IL, USA). One way Analysis of variance (ANOVA) with LSD-post hoc test was used to compare means of different groups. Based on the small sample used in this experiment it was recommended to use the Spearman correlation coefficient to detect associations urinary Nephrin and other study parameters in different groups. $p$ values $<0.05$ was the cutoff of significance.

\section{Results}

\section{Characteristics of diabetic nephropathy:}

As shown in Tables $(1,2)$, glucose level was significantly higher in DN groups in comparison to NC groups, with insignificant changes in Insulin indicating marked rise of HOAM-IR value (5.58 \pm 0.81 vs $1.73 \pm 0.58, p<0.001)$. The SOD activity was significantly lower, and MDA was significantly higher in the DN group. The manifestations of disturbed renal functions were also evident in form of significant rise of serum creatinine, serum urea, urinary protein, urinary protein-urinary creatinine ratio, urinary Nephrin, and mean arterial blood pressure, together with a significant reduction of urine flow, urinary creatinine, and GFR. Microscopic manifestations included marked interstitial inflammatory infiltrate, scattered fibrosis, and evident glomerulosclerosis in form of with diffuse and nodular mesangial expansion (Fig. 1, B vs A).

\section{Effects of ARB treatment:}

Candesartan treatment in rats with DN showed a significant reduction of glycemia, reduction of HOMA-IR value, amelioration of renal antioxidant system. Furthermore, candesartan improved the indicators of renal functions in the form of significant reductions in serum creatinine, reduction of proteinuria, reduction of the ration of urinary protein to creatinine, reduction of urinary Nephrin, and MABP. Histological improvement was also detected in the form of mild glomerulosclerosis and interstitial fibrosis (Fig. 1, D vs B). Interestingly these reno-protective roles were not significant in the physiological condition when comparing ARBtreated $\mathrm{NC}$ with the $\mathrm{NC}$ group.

\section{Role of nephrin:}

The urinary Nephrin was 90 times high in the condition of DN. This huge rise of urinary Nephrin was significantly reduced by Candesartan treatment. Moreover, correlation studies (Table 3) indicated that in the physiological conditions (group NC), the urinary Nephrin level showed a significant correlation with serum urea, urinary creatinine, and renal SOD activity. Besides, in diabetic nephropathy, Nephrin also showed a significant correlation with glucose level, serum creatinine, urinary protein-creatinine ratio, and MABP. 
Table (1): Studied parameters in all groups (represented as Mean \pm SD).

\begin{tabular}{lllll}
\hline \multicolumn{1}{c}{ Groups } & $\begin{array}{c}\text { Normal } \\
\text { Control } \\
(\mathrm{n}=8)\end{array}$ & $\begin{array}{c}\text { Diabetic } \\
\text { Nephropathy } \\
(\mathrm{n}=8)\end{array}$ & $\begin{array}{c}\text { ARB-treated } \\
\text { Normal Control } \\
(\mathrm{n}=8)\end{array}$ & $\begin{array}{c}\text { ARB-treated } \\
\text { Diabetic Nephropathy } \\
(\mathrm{n}=8)\end{array}$ \\
\hline Parameters & $80.17 \pm 9.64$ & $284.50 \pm 83.50 * * * \mathbf{a}$ & $83.50 \pm 11.02$ & $\begin{array}{l}227.83 \pm 40.19 * * * \mathbf{a}, * * \mathbf{b} \\
\text { Glucose (mg/d) }\end{array}$ \\
Insulin (uIU/l) & $8.83 \pm 0.94$ & $8.02 \pm 0.69$ & $7.98 \pm 0.70$ & $8.12 \pm 1.16$ \\
HOMA-IR & $1.73 \pm 0.58$ & $5.58 \pm 0.81 * * * \mathbf{a}$ & $1.63 \pm 0.15$ & $4.48 \pm 0.33 * * * \mathbf{a}, \mathbf{b}$ \\
Superoxide Dismutase (U/mg tissue protein) & $11.46 \pm 0.95$ & $5.17 \pm 0.65 * * * \mathbf{a}$ & $10.94 \pm 1.16$ & $6.78 \pm 1.11 * * * \mathbf{a}, * \mathbf{b}$ \\
Malondialdehyde (nmol/g tissue) & $35.65 \pm 2.71$ & $61.82 \pm 6.94 * * * \mathbf{a}$ & $34.61 \pm 2.67$ & $47.02 \pm 2.27 * * * \mathbf{a}, \mathbf{b}$ \\
\hline
\end{tabular}

$* * *=p<0.001 . * *=p<0.01 . *=p<0.05 . \quad$ a: Versus NC Group. $\quad$ b: Versus DN Group.

Table (2): Renal function parameters in all groups (represented as Mean $\pm \mathrm{SD}$ ).

\begin{tabular}{lllll}
\hline \multicolumn{1}{c}{ Groups } & $\begin{array}{l}\text { Normal } \\
\text { Control } \\
(\mathrm{n}=8)\end{array}$ & $\begin{array}{c}\text { Diabetic } \\
\text { Nephropathy } \\
(\mathrm{n}=8)\end{array}$ & $\begin{array}{c}\text { ARB-treated } \\
\text { Normal Control } \\
(\mathrm{n}=8)\end{array}$ & $\begin{array}{c}\text { ARB-treated } \\
\text { Diabetic Nephropathy } \\
(\mathrm{n}=8)\end{array}$ \\
Parameters & $0.63 \pm 0.11$ & $2.72 \pm 0.53 * * * \mathbf{a}$ & $0.65 \pm 0.16$ & $\begin{array}{c}2.12 \pm 0.22 * * * \mathbf{a}, * * \mathbf{b} \\
3\end{array}$ \\
\hline Serum Creatinine $(\mathrm{mg} / \mathrm{dl})$ & $25.15 \pm 3.32$ & $43.17 \pm 7.28 * * * \mathbf{a}$ & $23.67 \pm 5.43$ & $39.83 \pm 3.66 * * * \mathbf{a}$ \\
Serum Urea $(\mathrm{mg} / \mathrm{dl})$ & $48.83 \pm 3.43$ & $22.33 \pm 4.55 * * * \mathbf{a}$ & $49.67 \pm 4.32$ & $32.67 \pm 6.71 * * * \mathbf{a}, * * \mathbf{b}$ \\
Urinary creatinine $(\mathrm{mg} / \mathrm{dl})$ & $4.38 \pm 1.28$ & $36.17 \pm 6.24 * * * \mathbf{a}$ & $4.77 \pm 0.37$ & $25.08 \pm 5.30 * * * \mathbf{a}, \mathbf{b}$ \\
Urinary protein $(\mathrm{mg} / \mathrm{dl})$ & $0.0076 \pm 0.0007$ & $0.0038 \pm 0.0008 * * * \mathbf{a}$ & $0.0071 \pm 0.0012$ & $0.0029 \pm 0.0009 * * * * \mathbf{a}$ \\
Urine flow $(\mathrm{ml} / \mathrm{min})$ & $0.61 \pm 0.16$ & $0.03 \pm 0.01 * * * \mathbf{a}$ & $0.59 \pm 0.22$ & $0.04 \pm 0.01 * * * \mathbf{a}$ \\
Glomerular filtration rate $(\mathrm{ml} / \mathrm{min})$ & $0.09 \pm 0.2$ & $1.64 \pm 0.19 * * * \mathbf{a}$ & $0.10 \pm 0.01$ & $0.80 \pm 0.23 * * * \mathbf{a}, \mathbf{b}$ \\
Urinary Protein-Urinary Creatinine Ratio & $0.049 \pm 0.005$ & $4.47 \pm 0.78^{*} * * \mathbf{a}$ & $0.047 \pm 0.005$ & $2.043 \pm 0.892 * * * \mathbf{a}, \mathbf{b}$ \\
Urinary Nephrin $(\mu \mathrm{g} / 24 \mathrm{~h})$ & $84.92 \pm 5.43$ & $144.20 \pm 9.35 * * * \mathbf{a}$ & $77.33 \pm 14.69$ & $90.50 \pm 15.33 * * * \mathbf{b}$ \\
MABP $(\mathrm{mmHg})$ & & &
\end{tabular}

$* * *=p<0.001 . \quad * *=p<0.01 . \quad *=p<0.05 . \quad$ a: Versus NC Group. $\quad$ b: Versus DN Group.

Table (3): Correlation coefficientofurinary Nephrin with other studied parameters in all groups.

\begin{tabular}{lllcc}
\hline \multicolumn{1}{c}{ Groups } & $\begin{array}{c}\text { Normal } \\
\text { Control } \\
(\mathrm{n}=8)\end{array}$ & $\begin{array}{c}\text { Diabetic } \\
\text { Nephropathy } \\
(\mathrm{n}=8)\end{array}$ & $\begin{array}{c}\text { ARB-treated } \\
\text { Normal Control } \\
(\mathrm{n}=8)\end{array}$ & $\begin{array}{c}\text { ARB-treated } \\
\text { Diabetic Nephropathy } \\
(\mathrm{n}=8)\end{array}$ \\
\hline Glucose & 0.543 & $0.714^{*}$ & 0.406 & 0.314 \\
Insulin & -0.486 & 0.486 & 0.143 & 0.143 \\
HOMA-IR & 0.486 & 0.543 & -0.256 & -0.200 \\
Serum Creatinine & 0.257 & $0.667^{*}$ & -0.145 & 0.543 \\
Serum Urea & $0.657^{*}$ & 0.601 & 0.319 & $0.754^{*}$ \\
Urinary Creatinine & $0.899 *$ & 0.543 & 0.257 & -0.086 \\
Urinary Protein & 0.468 & 0.429 & 0.518 & 0.467 \\
Urine flow & 0.413 & -0.543 & 0.029 & -0.174 \\
Glomerular filtration rate & 0.200 & -0.257 & 0.143 & 0.429 \\
Urinary Protein-Urinary Creatinine Ratio & 0.257 & $0.771^{*}$ & -0.029 & $0.725^{*}$ \\
SOD & $-0.943 * *$ & -0.314 & -0.371 & -0.429 \\
MDA & 0.429 & -0.029 & 0.371 & 0.316 \\
MABP & -0.029 & $0.765^{*}$ & -0.212 & 0.429 \\
\hline
\end{tabular}

$* *=p<0.01 . * 2=p<0.05$. 

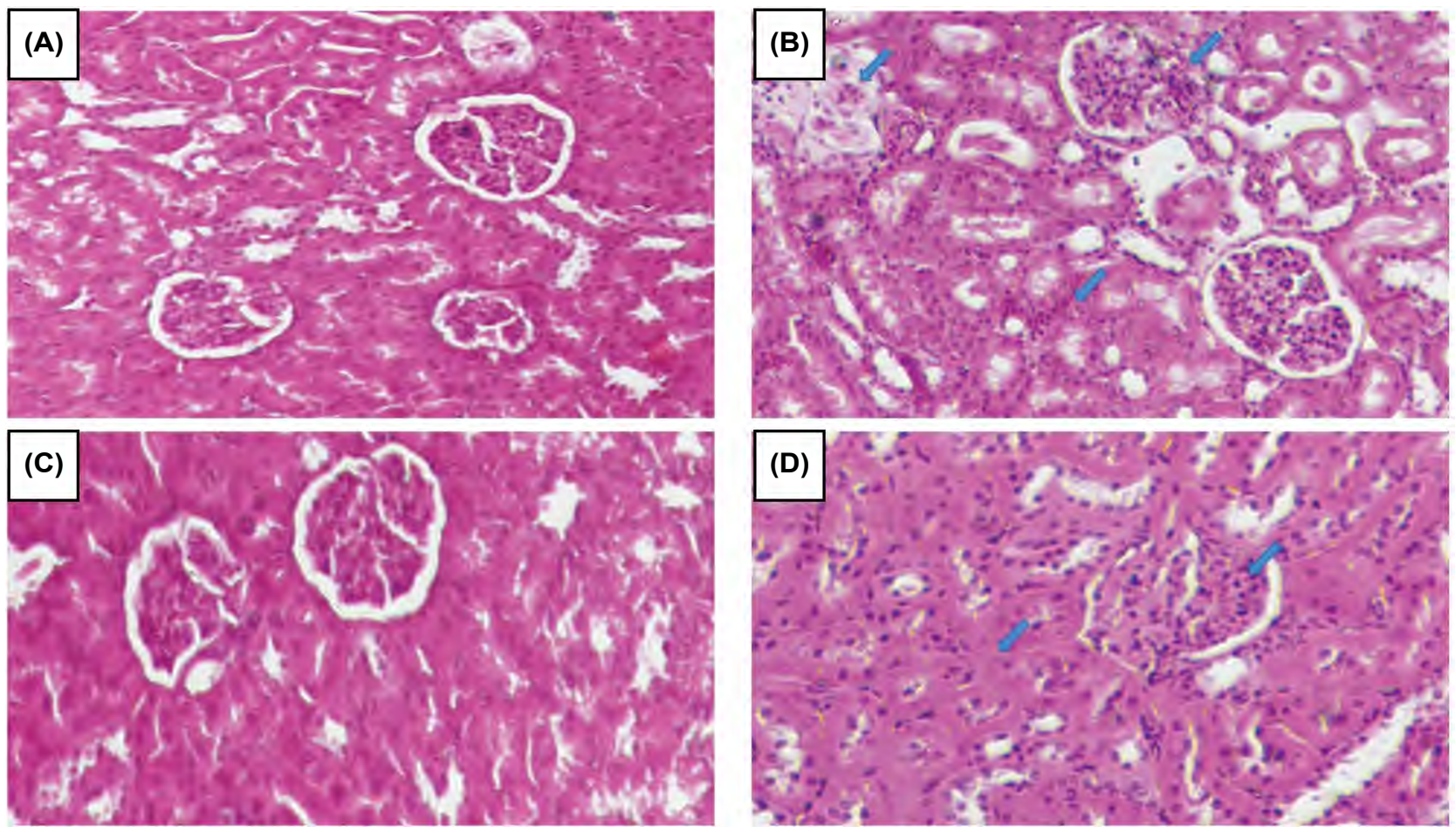

Fig. (1): Histopathological changes in the studied groups (H\&E staining x200). A=Normal control group; B=Diabetic nephropathy group; C=ATII-RB treated Normal Control group; D=ATII-RB treated Diabetic Nephropathy group. Arrows showing the area of interstitial inflammatory infiltrate, fibrosis and glomerulosclerosis.

\section{Discussion}

Renal impairment is one of the most commonpathological changes that is closelyrelated todiabetes mellitus [23]. Shaw JE, et al. (2010) [24] reported that most cases of end-stage renal diseases in the United States evoked by DM.

For a better understanding of pathological changes in DN, the Renal Pathology Society provide a new pathological classification of the histopathological changes in DN depending mainly on the glomerular changes and dividing it into 4 classes: Class I: Shows mainly thickening of the glomerular basement membrane; Class IIa: Shows mild mesangial expansion; Class IIb: Shows severe mesangial expansion; Class III: Shows nodular sclerosis and finally Class IV: Shows global glomerulosclerosis in more than $50 \%$ of glomeruli [25].

Owing to the great resemblance of the histopathological changes associated with diabetic nephropathy in rats and humans [26], in the present study we have produced a model of diabetic nephropathy by intraperitoneal injection of STZ.

The results of this study showed the presence of histopathological changes in STZ-induced diabetic groups in the form of marked interstitial inflammatory infiltrate with scattered fibrosis and evident glomerulosclerosis with diffuse and nodular mesangial expansion. These findings according to the new classification of the Renal Pathology Society could be considered as class IV DN.

In addition, there was a marked elevation in serum glucose level and HOMA-IR value accompanied with marked disturbance in renal functions in the form of a significant rise in serum creatinine, serum urea, urinary protein, urinary protein-urinary creatinine ratio, together with a significant reduction of urine flow, urinary creatinine, and GFR in STZinduced diabetic groups when compared to $\mathrm{NC}$ groups.

Various factors involved in the pathogenesis of DN besides the genetic predisposition as the activation of the Renin-Angiotensin-Aldosterone system (RAAS), reactive oxygen species (ROS), and the increase of advanced glycation end-products [27].

It has been shown that the oxidative stress induced by chronic hyperglycemia mayplaya role in the development and pathogenesis of DN [28]. Furthermore, Jia J et al. (2008) [29] reported that chronic hyperglycemia could produce renal oxidative injury by stimulating oxidative stress with over production of ROS.

The renal cells are more vulnerable to oxidative injury due to their high rate of oxygen consumption; 
therefore this oxidative injury is usually associated with enzymatic inactivation in the form of impaired lipid peroxidation with the enhancement of MDA production [30].

On the other hand, renal cells characterized by a normal physiological defense mechanism, as they contain endogenous cellular antioxidant system which counteracts to a certain limit the harmful effects of over production of ROS [31].

These reports are consistent with the results of this study. As in the present study, the DN group showed a significant elevation of MDA which is an indicator of ROS over-activity and a marked reduction in SOD that indicates the depletion of the endogenous antioxidant activity of renal tissues.

Interestingly, the candesartan-treated group in this study showed significant improvement of the antioxidant capability of renal cells in the form of a significant elevation of serum SOD level with a significant reduction of serum MDA indicating one of the different mechanisms of candesartan in treatment and prevention of DN. This was contrary to the finding of Sugimoto et al. (2005) [32] which proves that both candesartan and enalapril insignificantly change the antioxidant levels in kidney tissue of the 5/6 nephrectomized rats. The different rat models may put the interpretation of this discrepancy.

Furthermore, the ROS overproduction could induce mitochondrial-dependent apoptotic pathway through the overexpression of different apoptotic protein e.g. Bax and cleaved caspase- 3 with subsequent injury and apoptosis of renal cells mainly podocytes, that play also an important role in the pathogenesis of DN [33].

Although the role of RAAS in the pathogenesis of DN is extensively studied, the exact mechanisms still need to be completely elucidated [34]. Giacchetti et al. (2005) [35] reported that hyperglycemia induces over production of Angiotensin II (Ang II) which induces through different local mediators e.g. oxygen free radicals and inflammatory mediators endothelial cell damage and renal vascular remodeling. Also, Magee et al. (2017) [36] showed that the progression of the $\mathrm{DN}$ is strongly correlated to insulin resistance, which could be deteriorated through the overactivity of RAAS in renal tissues.

These results are consistent with the result of the current study as the STZ-induced diabetic rats hav ingelevated HOMA-IR value showed a significant reduction in HOMA-IR value under candesartan therapy.
Several previous studies assumed that the RAAS and oxidative stress could mutually control each other through diverse mechanisms and participate in the development of DN [37]. Ang II together with ROS may be responsible for organ damage through activation of proinflammatory, profibrotic, and mitogenic signaling pathways [38].

Different studies showed increased activity of Mitogen-activated protein kinases (MAPKs) which is the main signaling pathway in fibrosis, inflammation, and mitosis in renal tissuesin diabetic subjects [39]. So, in this study, the activity of MAPKs could be suppressed by candesartan therapyas ATII-RB indicating that the role of ATII$\mathrm{RBs}$ in diabetic nephropathy is independent of its antihypertensive effect.

The present study observed that candesartan treatment in rats with DN significantly improved the indicators of renal functions in the form of a significant reduction in serum creatinine and reduction of proteinuria. Also, the histological improvement was detected in the form of mild glomerulosclerosis and interstitial fibrosis. These findings are consistent with those of Mimran and Alfaro (2003) [40] who reported the beneficial effects of candesartan in blocking angiotensin receptors and decreasing renal vascular resistance \& urinary albumin excretion.

The occurrence of albuminuria indicates either structural or functional changes in the glomerular filtration barrier (GFB) [41]. Maezawa et al. (2015) [42] found that in DN podocytes which are the most important element of GFB wasexposed to marked apoptosis through ROS which activates NADPH oxidase with subsequent micro-and macroalbuminuria, which agrees with our assumption about the pathogenesis of DN.

Nephrin is a recently discovered protein that is considered as the slit diaphragm of the podocytes. Besides, the integrity of the podocyte filtration barrier depends mainly on the vitality of Nephrin expression [5]. Recent research essuggested a significant declinein Nephrin expression and marked increased inurinary Nephrin in diabetic kidney diseases [43]. Moreover, Pan et al. (2018) [44] proved that some compounds like catalpol possess a renoprotective effect that may improve the glomerular filtration barrier in DN through enhancement of Nephrin expression.

In the present study, we examined the role of the RAAS and its blocker candesartan on the podocytes and Nephrin activity. The results of this 
study revealed marked elevation of urinary Nephrin (90 times high) in the condition of DN. This huge rise of urinary Nephrin was significantly reduced by Candesartan treatment. The latter finding is consistent with the suppressive effect of candesartan on Nephrin gene expression in hypertensive nephropathy [45].

Moreover, correlation studies indicated that in the physiological conditions (group NC), the urinary Nephrin level showed a significant correlation with serum urea, urinary creatinine, and renal SOD activity. Also, in diabetic nephropathy, Nephrin showed significant correlations with glucose level, serum creatinine, urinary protein-creatinine ratio, and MABP.

The present study supposes that the RAAS in combination with ROS through MAPKs regulates the apoptotic activity of different renal cells including podocytes. So, this assumption coincides with some recent studies that reported significant disturbance in the podocytes of GFB with subsequent disturbance in Nephrin expression in DN [46].

Finally, this study concludes that candesartan as ATII-RB could reduce urinary Nephrin excretion and possibly alters its expression through its inhibitory effect on the ROS and RAAS and subsequently maintains the normal physiological activity of podocytes in rats with STZ-induced diabetic nephropathy.

Acknowledgment: To Dr. Hanan Lotfy, Lecturer of Pathology, Zagazig Univerisity, Faculty of Medicine, for assistance in preparation, staining, and reporting of the pathology sections.

\section{References}

1- KALLURI R.: Proteinuria with and without renal glomerular podocyte effacement. J. Am. Soc. Nephrol., 17: 23839, 2006.

2- KOMICI K., FERMMINELLA G.D., DE LUCIA C., CANNAVO A., BENCIVENGA L., CORBI G., LEOSCO D., FERRARA N. and RENGO G.: Predisposing factors to heart failure in diabetic nephropathy: A look at the sympathetic nervous system hyperactivity. Aging Clin. Exp. Res., 31: 321-330, 2018.

3- COOPER M.E.: Interaction of metabolic and haemodynamic factors in mediating experimental diabetic nephropathy. Diabetologia, 44: 1957-1972, 2001.

4- REMUZZI G., BENIGNI A. and REMUZZI A.: Mechanisms of progression and regression of renal lesions of chronic nephropathies and diabetes. J. Clin. Invest., 116: 288-296, 2006.

5- TAGAWA A., YASUDA M., KUME S., YAMAHARA K., NAKAZAWA J. and Chin-KANASAKI M.: Impaired podocyte autophagy exacerbates proteinuria in diabetic nephropathy. Diabetes, 65: 755-767, 2016.

6- SIFUENTES-FRANCO S., PADILLA-TEJEDA D.E., CARRILLO-IBRRA S. and MIRANDA-DIAZ A.G.: Oxidative stress, apoptosis, and mitochondrial function in diabetic nephropathy. Int. J. Endocrinol. 2018, 1875870, 2018.

7- PAN Y., JIANG S., HOU Q., QIU D., SHI J., WANG L. CHEN Z., ZHANG M., DUAN A., QIN W., ZEN K. and LIU Z.: Dissection of glomerular transcriptional profile in patients with diabetic nephropathy: SRGAP2a protects podocyte structure and function. Diabetes, 67: 717-730, 2018.

8- ONOZATO M.L., TOJO A., GOTO A., FUJTA T. and WILCOX C.S.: Oxidative stress and nitric oxide synthase in rat diabetic nephropathy: Effects of ACEI and ARB. Kidney Int., 61: 186-194, 2002.

9- OGAWA S., TAKEUCHI K., MORI T., NAKO K. and TSUBONO Y.: Effects of monotherapy of temocapril or candesartan with dose increments or combination therapy with both drugs on the suppression of diabetic nephropathy, Hypertens. Res., 30: 325 - 334, 2007.

10- YU C., GONG R., RIFAI A., TOLBERT E.M. and DWORKIN L.D.: Long-term, high-dosage candesartan suppresses inflammation and injury in chronic kidney disease: Nonhemodynamic renal protection, J. Am. Soc. Nephrol., 18: 750-759, 2007.

11-INSTITUTE OF LABORATORY ANIMAL RESOURCES, COMMISSION ON LIFE SCIENCES AND NATIONAL RESEARCH COUNCIL: Guide for the care and use of laboratory animals, 8thEdition. National academy press, Washington D.C., 21-55, 1996.

12- MESSIER C., WHATELY K., LIANG J., DU L. and PUISSANT D.: The effects of a high-fat, high-fructose, and combination diet on learning, weight, and glucose regulation in C57BL/6 mice. Behavioural Brain Research, 178 (1): 139-45, 2007.

13- SRINIVASAN K., VISWANAD B., ASRAT L., KAUL C.L. and RAMARAO P.: Combination of high-fat dietfed and low-dose streptozotocin-treated rat: A model for type 2 diabetes and pharmacological screening. Pharmacol. Res., 52: 313-320, 2005.

14- MIMA A., ARAI H. and MATSUBARA T.: Urinary Smad1 is a novel marker to predict later onset of mesangial matrix expansion in diabetic nephropathy. Diabetes, 57 (6): 1712-1722, 2008.

15- BRASZKO J.J., WINCEWICZ D. and JAKUBOW P.: Candesartan prevents impairment of recall causedby repeated stress in rats. Psychopharmacology, 225: 421$428,2013$.

16- BAZZANOL T., RESTEL I.T., PORFIRIOLL L.C., DE SOUZA A.S. and SILVA I.S.: Renal biomarkers of male and female Wistar rats (Rattus norvegicus) undergoing renal ischemia and reperfusion. Acta Cirúrgica Brasileira, 30 (4): 277-288, 2015.

17- DE CASTRO B.B.A., COLUGNATI F. A. B., CENEDEZE M. A., SUASSUNA P.G.A. and PINHEIRO H.S: Standardization of renal function evaluation in Wistar rats (Rattus norvegicus) from the Federal University of Juiz de Fora's colony J. Bras Nefrol., 36 (2): 139-149, 2014. 
18- LI L., CHEN Z., WANG Y., ZHANG J., YIN Z., LI L., ZHANG X. and WANG F.: Relationship between urinary Nephrin and urinary albumin changesin diabetic rats and effects of Yiqiyangyinhuayutongluo Recipe. J. Tradit Chin. Med., 32 (2): 278-282, 2012.

19- ŞEN S. and ÇELIK S.: The effect of acetylsalicylic acid on vasopressin, serum insulin levels, insulin resistance, and biochemical parameters in rats induced with experimental diabetes type 2. Turk J. Med. Sci., 47: 996-1001, 2017.

20- MATTHEWS D.R., HOSKER J.P., RUDENSKI A.S., NAYLOR B.A., TREACHER D.F. and TURNER RC.: Homeostasis model 320 assessment: Insulin resistance and $\beta$-cell function from fasting plasma glucose and insulin 321 concentrations in man. Diabetologia, 28: 4129, 1985.

21- ZHANG S., XU H., YU X., WU Y. and SUI D.: Metformin ameliorates diabetic nephropathy in a rat model of lowdose streptozotocin-induced diabetes. Experimental and Therapeutic Medicine, 14 (1): 383-390, 2017.

22- TREMOLEDA J.L., KERTON A. and GSELL W.: Anaesthesiaand physiological monitoring during in vivo imaging of laboratory rodents: Considerations on experimental outcomes and animal welfare. EJNMMI Res., 2 (1): 4447, 2012.

23- CHUANG P.Y., YU Q., FANG W., URIBARRI J. and HE J.C.: Advanced glycation endproducts induce podocyte apoptosis by activation of the FOXO4 transcription factor. Kidney Int., 72: 965-76, 2007.

24- SHAW J.E., SICREE R.A. and ZIMMET P.Z.: Global estimates of the prevalence of diabetes for 2010 and 2030. Diabetes Res. Clin. Prac., 87: 4-14, 2010.

25- TERVAERT T.W., MOOYAART A.L., AMANN K., COHEN A.H., COOK H.T., DRACHENBERG C.B., FERRARIO F., FOGO A.B., HAAS M., HEER E., JOH K., NOEL L.H., RADHAKRISHNAN J. SESHAN S.V., BAJEMA I.M. and BRUIJIN J.A.: Pathologic classification of diabetic nephropathy. J. Am. Soc. Nephrol., 21: 55663. 2010.

26- YAMAMOTO T., NAKAMURA T., NOBLE N.A., RUOSLAHTI E. and BORDER W.A.: Expression of transforming growth factor beta is elevated in human an experimental diabetic nephropathy. Proc. Natl. Acad. Sci. USA, 90: 1814-18, 1993.

27- CHAU M.K., ZHANG Q., ZHANG C.Z. and CHAN T.M.: Sulodexide decreases albuminuria and regulates matrix protein accumulation in C57BL/6 mice with streptozotocin-induced type I diabetic nephropathy. PloS One., 8: e54501, 2013.

28- MA S.T, LIU D.L., DENG J.J., NIU R. and LIU R.B.: Effect of arctiin on glomerular filtration barrier damage in STZ-induced diabetic nephropathy rats", Phytotherapy Research, 27 (10): 1474-1480, 2013.

29- JIA J., DING G., ZHU J., CHEN C., LIANG W., FRANKI N. and SINGHAL P.C.: Angiotensin II infusion induces Nephrin expression changes and podocyte apoptosis. Am. J. Nephrol., 28: 500-7, 2008.

30- SUSZTAK K., RAFF A.C., SCHIFFER M. and BOTTINGER E.P.: Glucose-induced reactive oxygen species cause apoptosis of podocytes and pdocyte depletion at the onset of diabetic nephropathy. Diabetes., 55: 225-33, 2006.

31- HEYMAN S.N., ROSEN S., KHAMAISI M., IDEE J.M. and ROSENBERGER C.: Reactive oxygen species and the pathogenesis of radiocontrast-induced nephropathy," Investigative Radiology, 45 (4): 188-195, 2010.

32- SUGIMOTO K., TSURUOKA S., MATSUSHITA K. and FUJIMURA A.: Effects of candesartan cilexetil on oxidative state and renal function in 5/6 nephrectomized rats. Journal of Human Hypertension, 13 (Suppl 1): S63-S70, 1999.

33- CHAITANYA G.V., ALEXANDER J.X. and BABU P.P.: PARP-1 cleavage fragments: Signatures of cell-death proteases in neurodegeneration", Cell Communication and Signaling, 8 (1): 31, 2010.

34- KOMICI K., FEMMINELLA G.D., DE LUCIA C., CANNAVO A., BENCIVENGA L., CORBI G., LEOSCO D., FERRARA N. and RENGO G.: Predisposing factors to heart failure in diabetic nephropathy: A look at the sympathetic nervous system hyperactivity. Aging Clin. Exp. Res., 31: 321-330, 2018.

35- GIACCHETTI G., SECHI L.A., RILLI S. and CAREY R.M.: The renin-angiotensin-aldosterone system, glucose metabolism and diabetes. Trends Endocrinol. Metab., 16: 120-126, 2005.

36- MAGEE C., GRIEVE D.J., WATSON C.J. and BRAZIL D.P.: Diabetic nephropathy: A tangled web to unweave. Cardiovoasc Drugs Ther., 31: 579-592, 2017.

37- PATEL K.P., MAYHAN W.G., BIDASEE K.R. and ZHENG H.: Enhanced angiotensin II-mediated central sympathoexcitation in streptozotocin-induced diabetes: Role of superoxide anion. Am. J. Physiol. Regul Integr Comp Physiol., 300: R311-320, 2011.

38- CAT N.D.C., MONTEZANO A.C., BURGER D. and TOUYZ R.M.: Angiotensin II, NADPH oxidase, and redox signaling in the vasculature, Antioxid. Redox Signal., 19: 1110-1120, 2013.

39- FELIERS D., DURAISAMY S., FAULKNER J.L., DUCH J., LEE A.V., ABBOUD H.E., CHOUDHURY G.G. and KASINA B.S.: Activation of renal signaling pathways in $\mathrm{db} / \mathrm{db}$ mice with type 2 diabetes, Kidney Int., 60: 495504. 2001.

40- MIMRAN A. and ALFARO V.: Candesartan: Nephroprotective effects and treatment of diabetic nephropathy. Drugs Today (Barc)., 39 (6): 439-50, 2003.

41- DECLEVES A.E. and SHARMA K.: New pharmacological treatments for improving renal outcomes in diabetes. Nat. Rev. Nephrol., 6: 371-80, 2010.

42- MAEZAWA Y., TAKEMOTO M. and YOKOTE K.: Cell biology of diabetic nephropathy: Roles of endothelial cells, tubulointerstitial cells and podocytes. J. Diabetes Investig., 6: 3-15, 2015.

43- TROHATOU O., TSILIBARY E.F., CHARONIS A., IATROU C. and DROSSOPOULOU G.: Vitamin D3 ameliorates podocyte injury through the Nephrin signalling pathway. J. Cell. Mol. Med., 21: 2599-2609, 2017. 
44- PAN Y., JIANG S., HOU Q., QIU D., SHI J., WANG L., CHEN Z., ZHANG M., DUAN A., WEISNG Q., ZEN K. and LIU Z.: Dissection of glomerular transcriptional profile in patients with diabetic nephropathy: SRGAP2a protects podocyte structure and function. Diabetes, 67: 717-730, 2018.

45- KATO T., MIZUGUCHI N. and ITO A.: Candesartan suppresses proteinuria and decrease of nephrin expression but hydralazine does not in hypertensive nephropathy. J. Biomed., 2: 57-63, 2017.

46- JIN J., TU, Q., GONG J., ZHAO L., LIANG S. and HE Q.: Autophagy activity and expression pattern of autophagy-related markers in the podocytes of patients with lupus nephritis: Association with pathological classification. Ren. Fail., 41: 294-302, 2019.

\section{التأثير الواقى لحاصرات مستقبلات الانجيوتنسين II من النوع الأول على الكلى فى حالات الاعتلال الكلوى السكري دور النفرين}

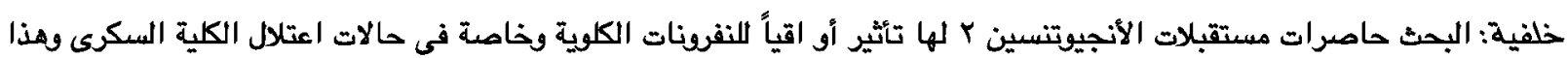

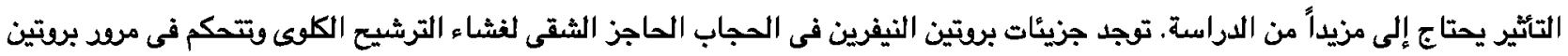

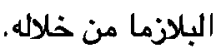

الهدف من العمل: دراسة الدود المحتمل لبروتين النيفرين فى التسبب فى اعتالال الكلية السكرى ودوده في التأثير الوقائى لحاصرات مستقبلات الأنجيوتنسين ب مثل الكانديسارتان على اعتلال الكية النية السكرى.

المواد والأساليب: تم استخدام اثثين وثلاثين من الفئران الذكود فى هذه التجرية. تم تفذية نصف الفئران بنظام غذائى غنى بالدهون

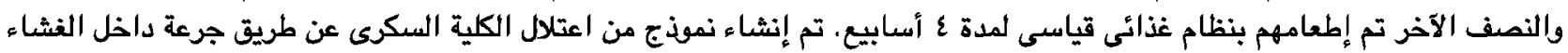

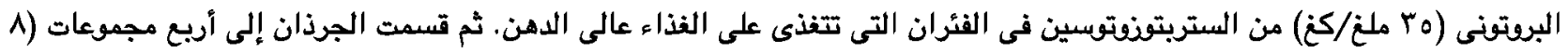

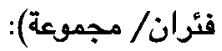
- المجموعة الأولى: المجموعة الضابطة الطبيعية.

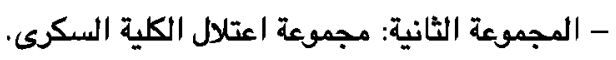

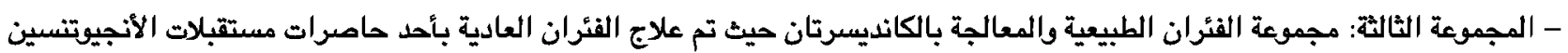

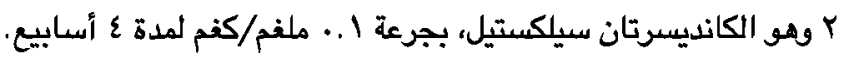

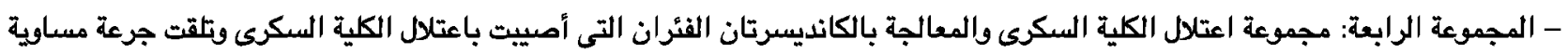
لما ذكر أعلاه من دواء الكانديسارتان لمدة ع ع أسعابيع.

تم جمع البول لقياس معدل تدفق البول والتركيزات البولية من النيفرين والكرياتينين والبوتينين. تم استخدان عينات الدم لقياس اليوريا

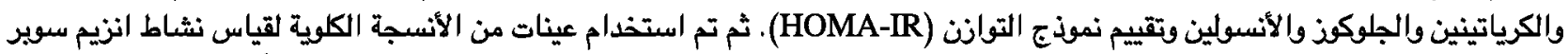

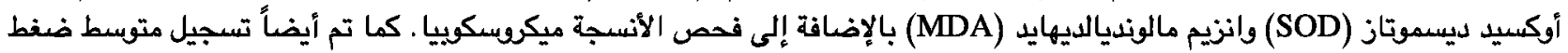
الدم الشريانى من ذيل الفئران.

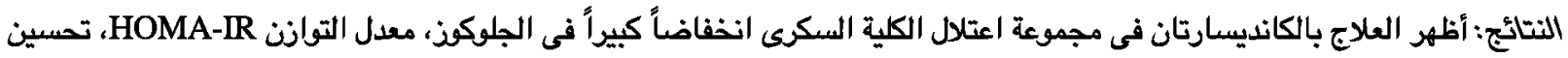

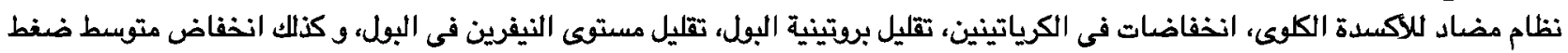

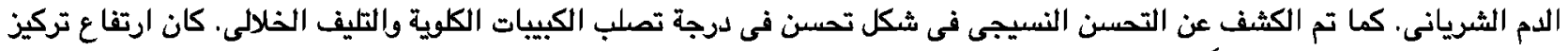

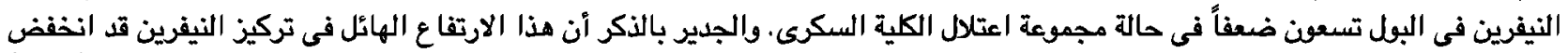

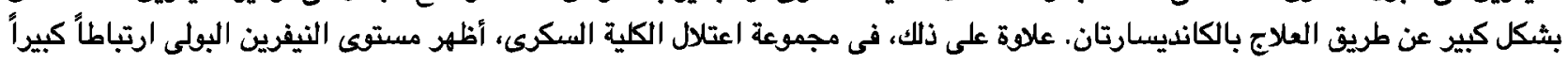

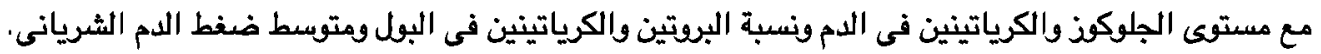

الخلاصة: يمكن لحاصرات مستقبلات الأنجيوتنسين Y أن تقلل إفراز النيفرين فى البول وأيضاً ريما تغير منتكوين النيفرين من خلال

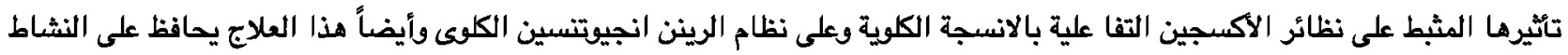

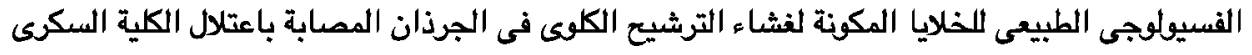

